\title{
Response to citation by Gerhard Wörner
}

\author{
Hans-Ulrich Schmincke
}

Published online: 3 January 2014

(C) Springer-Verlag Berlin Heidelberg 2013

\section{Socrates (via Plato, some time ago): I know that I know nothing}

The Steinmann medal, nominally bestowed on individuals, in reality honors the scientific accomplishments of many people, foremost the tens of young people, my former MA (Diploma) and PhD students and postdocs, who were at the core of most of our scientific projects bringing them to fruition through their dedication and perseverance, painstaking donkey work, and novel ideas. The honor also acknowledges the discipline of volcanology that lay dormant in this country for a long time. It took some effort to free it from the Babylonian captivity having led a marginal existence in the country's mineralogy departments, Earth science at our universities having been painfully subdivided into separate institutes for far too many decades to the benefit of Herr Professor Dr. The fascination with titles is still with us including a dose of hierarchical attitude, here and there developing into power harassment. Volcanology belongs to neither mineralogy, nor tectonics, sedimentology, geophysics, stratigraphy nor any other field. Volcanology is essentially an Earth science system discipline. It is basically concerned with broad interdisciplinary scientific problems-increasingly also societal needs-not methods. About 15 years ago, we expanded the previously used definition of our scientific approach-volcano-magma system-into internal and external forcing of volcano-magma systems recognizing that external factors are fundamental in triggering and governing volcanic eruptions and their products. I habilitated-a queer and entirely obsolete German academic tradition required to earn the license to teach-in

H.-U. Schmincke $(\bowtie)$

GEOMAR Helmholtz Center of Ocean Research, Kiel, Germany

e-mail: h-u.schmincke@t-online.de both geology and petrology to get around the problem of becoming locked into the jealously guarded subdisciplines.

This introduction reflects the major impact of 4 years as a graduate student in the US where I became immersed in an academic world that contrasted starkly with what I had experienced during the first 2 years as a beginning student in Germany. Gerd, in his most gracious eulogy, touched upon the fact that my stint at two US American universities (Johns Hopkins and UC Santa Barbara) had a decisive influence on my academic roots. Indeed, the contrast between the almost hierarchy-free academic atmosphere at American graduate schools was so much to my liking that I would have returned to the States a few years later had it not been for my growing family and-outside Arcadiasome aspects of US dominance that can be disturbing.

Among my teachers, AC Waters and FJ Pettijohn were especially influential-although their actual involvement in my PhD field and laboratory work was marginal, Waters, my main advisor, having never visited me in the field. Indeed, our teachers at Johns Hopkins strongly encouraged independence-apart from being deeply human toward graduate students. One should not forget, however, that life in US graduate schools is no bed of roses consisting as it does of hard work 7 days a week from 9 in the morning to $22 \mathrm{~h}$ at night.

During my PhD work on flood basalts (1962-1964), I was just interested in solving long-standing problems, basically probing the unknown. Current topics such as hazards, risks, geothermal energy, ore deposits, climate, soils or other societal needs and demands related to volcanoes, unavoidable buzz words in any current volcanological research proposal, were not on my mind nor on that of my fellow students at the time, curiosity being powerful enough to fuel our dedication: straightforward fundamental science. I focused on characterizing individual flood basalt 
sheets structurally and compositionally, and to trace them and their sedimentary interbeds for hundreds of square kilometers. At the top secret Hanford industrial complex, geographically in the center of my thesis area, plutonium had been produced for the nuclear bomb that annihilated Nagasaki (Japan). The radioactive waste was pumped into hundreds of wells sunk into the flood basalts, the major problem being the sedimentary interbeds along which the radioactive waters could seep toward the Columbia River. The basic stratigraphy I had worked out in the surrounding desolate mountains turned out to be a godsend to the Hanford geologists who monitored the underground migration of the contaminated waters. Success was ultimately marginal, however, Hanford becoming known internationally as the first site of a major radioactive environmental disaster.

The years 1960-1964 were also one of the most revolutionary periods in the modern history of the United States whose impact on my evolving grasp of public life and society was similarly profound. JF Kennedy, the hero of our generation, was elected soon after I had arrived in the US. The radio news of his assassination on 22.11 .1963 abruptly ended a day of working on my thesis, and for several days thereafter. Martin Luther King`s famous "I have a dream", 3 months earlier on 18.8.1963, highlighting his March on Capitol Hill, illuminated the fact that apartheid was still very much alive in the US in the mid-1960s. Another political revolution further sharpened my political awareness: The overdue student revolution, epitomized by Mario Savios famous "Free Speech movement" presentation at UC Berkeley on December 2, 1964, was a foreboding of things to come a few years later in Germany, France and other countries. King and Savio subsequently enjoyed lifelong surveillance by the FBI.

When returning to Germany in late 1964, I was naive to think that, by 1970 —at the latest—, BA and MA would have become fully integrated into our university system for good, real graduate schools be established, institutes be amalgamated into departments, assistant status and habilitation be abolished forever and obedience and submission be materially replaced by encouragement for self-confidence and courage. Little I knew. However, there were a few glimpses of hope. In 1965, the professors in Heidelberg strongly warned me-a 28 -year-old postdoc-against submitting a research proposal under my own name-without them as PI or only applicant—even though neither had any interest in, nor knowledge of, volcanology. I refused and, surprise, the Deutsche Forschungsgemeinschaft turned out to be liberal enough to accept my proposal. Indeed, the DFG was years ahead of most universities in this country and, until recently, the bread-and-butter organization that financially supported much of our research over 40 years.

Long-term changes in paradigms and shifts in personal and societal priorities (public funding) increasingly influenced my work and the motivation of my students over the decades. As early as the mid-seventies, we were approached by the German Federal Ministry of Research with the offer not only to fund $\mathrm{PhD}$ students but also to acquire hardware such as an XRF spectrometer without submitting a lengthy proposal. Much of our early work in the Eifel volcanic fields was also supported by European Community research funds, with the overarching goal to assess the potential for geothermal energy in the Eifel, triggered by the first energy crisis that had just shocked Europe in 1973 .

The fact that volcanoes-next to dinosaurs-captivate the imagination-especially of young people-more than anything else, motivated me early on to help bringing science to the people. Nowadays acknowledged, it was viewed with suspicion by the scientific community in the 1970s. Today, outreach activities have become an important duty in informing the public of the prudent use of research funds and in attempting to counterbalance the pervasive hype in print and TV media especially when the focus is on socalled natural disasters most in reality being societal disasters. Volcanoes per se are not dangerous.

My research stomping ground on foot, in ocean- and land-based drilling projects and in research ships was the globe - as for many earth scientists. It included exotic countries such as North Korea where we tried to reconstruct the sulfur emission and potential climate impact on ancient far east societies resulting from the large-magnitude 1,000-year-old eruption of Baitushan volcano. Nevertheless, we also maintained long-term research over four decades in two key areas-the Canary Islands including the surrounding ocean floor and the Eifel volcanic fields-in an attempt to increasingly improve our understanding of the inner workings of complex volcano-magma-atmosphere systems including potential hazards for society.

Um etwas wahrzunehmen/im Wirrwar der Erscheinungen,/suchst Du nach einem Muster./Kaum hast $D u$ es gefunden,/heckt es ein neues./Ist da kein Ende in Sicht?/Nein. Das iteriert/bis ins Bodenlose./Du mußt den Webfehler finden, den Makel der Mutation. HM Enzensberger, venerable leading poet and intellectual: Blauwärts (2013). 